\title{
Zeolite mineralogy of the Cayo formation in Guayaquil, Ecuador
}

\author{
L. Machiels , F. Morante , R. Snellings , B. Calvo , L. Canoira , C. Paredes , J. Elsen \\ Katholieke Universiteit Leuven, Laboratory of applied geology and mineralogy, Celestijnenlaan 200E, B-300I Heverlee, Belgium \\ Escuela Superior Politécnica del Litoral, Campus Gustavo Galindo Km. 30,5 Via Perimetral, P.O. Box 09-01-5863, Guayaquil, Ecuador \\ Escuela Técnica Superior de Ingenieros de Minas, Universidad Politécnica de Madrid, Ríos Rosas,21, 28003, Madrid, Spain
}

\begin{abstract}
This work shows the presence of zeolites in the Cretaceous Cayo formation in Coastal Ecuador. In the area of Guayaquil the Cayo formation consist of marine pyroclastic flow deposits, associated fallout tuffs and epiclastic rocks. The main zeolites are Ca-heulandite (mean Si/Al: 3.30 ) and Ca-clinoptilolite (mean Si/Al: 4.35). Less common are laumontite, mordenite and analcime. Zeolites compose 10-60\% of the rocks. The deposit is of great importance for Ecuador, considering its enormous zeolitised outcrop area (more than $10,000 \mathrm{~km}^{2}$ ).
\end{abstract}

Keywords: Natural zeolite; Heulandite; Clinoptilolite; Laumontite; Guayaquil

\section{Introduction}

This article presents the results of the research on the characterization of zeolite deposits of the Cayo formation located in the Ecuadorian Coastal Region near to Guayaquil city. Zeolites were first described in the region of Guayaquil in 1994 by a group of Cuban researchers (unpublished). The project "Sustratos Ecológicos a base de Zeolitas Naturales en la ESPOL" was set up in march 2000 , with the objective of investigating the zeolite occurrence and mineralogy in the area and the applications of zeolite minerals in agriculture, as building materials, in aquaculture and in other industrial and environmental applications.

The Cayo formation extends over an area more than $10,000 \mathrm{~km}^{2}$ (Fig. 1) which is zeolitised (Machiels et al., 2006). A deposit of this dimension can be of great importance for a developing country such as Ecuador. Previous authors described clinoptilolite in the
Cayo formation at the Perimetral ring way (Via Perimetral) and at the campus of the Escuela Superior Politécnica del Litoral (ESPOL University) near Guayaquil (Fig. 2, López et al., 2002; Nazareno et al., 2002). The lithology of the Cayo formation is very heterogeneous in this area, which results in great differences in zeolite mineralogy and content. At present only thin layers of green tuffs, locally named "lutita verde", which are rarely exposed in the area, are exploited. An intensive study of the geology and the mineralogy of the deposit is important for a more effective exploration and for a better exploitation of the zeolites. The aim of this study is to obtain a depositional, petrographical and mineralogical characterization of the deposit.

Recently the first small-scale zeolite quarries exploiting the Cayo formation began operations. So far the minerals are mainly used in agriculture as fertilizer carriers but their potential use as molecular sieve, absorbent or ion-exchanger in specific local applications has been described previously (Morante, 2004). Zeolites could be used for the purification of the waste waters of Guayaquil, a city of more than 3 million inhabitants, as fertilizer carriers in banana or coffee plantations or for the absorption of ammonia from shrimp breeding pools. A great demand for the use of zeolites comes from the local cement production industry, for the development of low-cost puzzolanic cements. Zeolites of this deposit are well suited for the use as a 


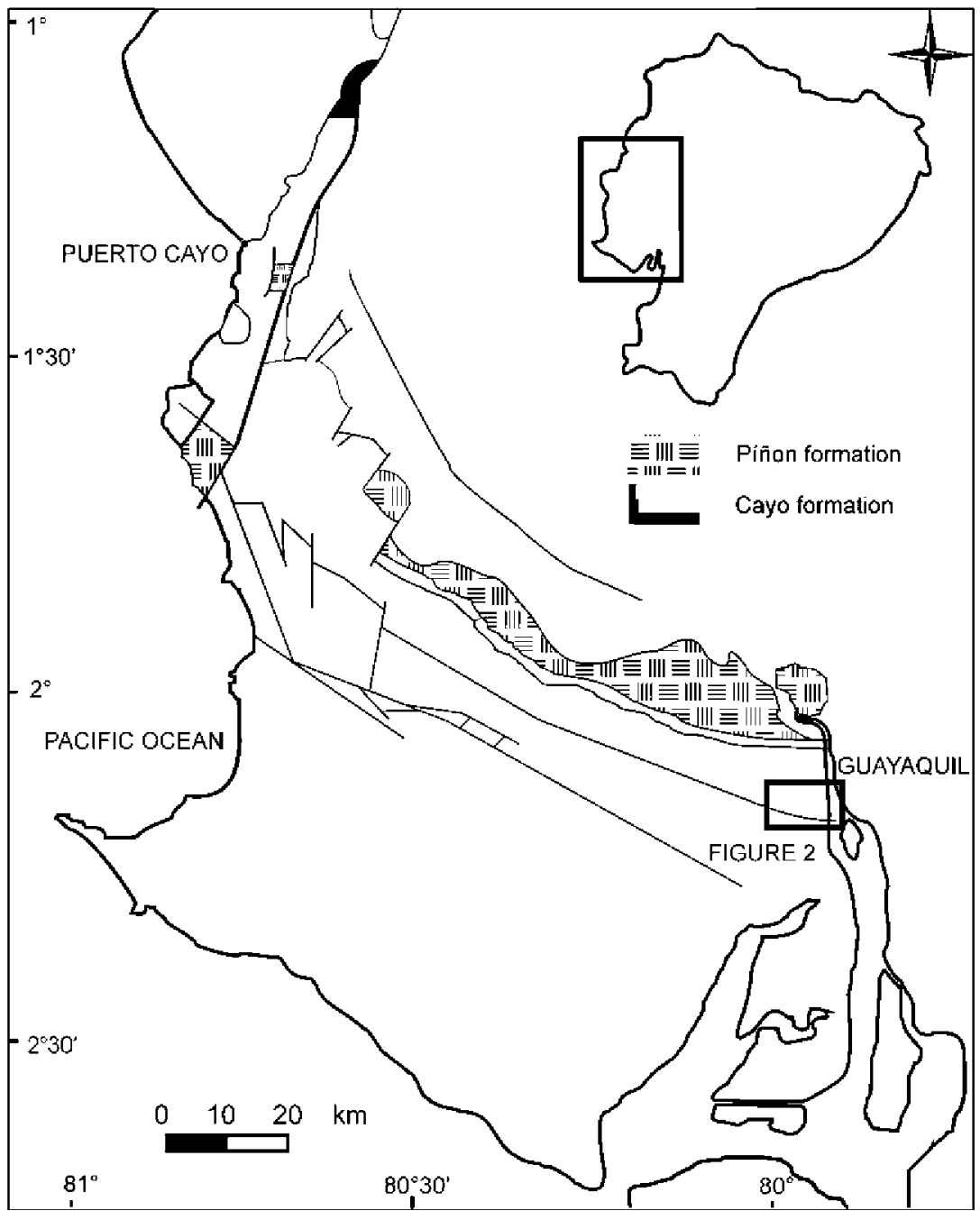

Fig. 1. Outcrop area of the Cayo formation in the Cordillera Chongón-Colonche. Modified from Reynaud et al. (1999) and Mamberti et al. (2003).

natural puzzolana (Robalino et al., 2005) and thus can be added to Portland cement.

\section{Geology of the Ecuadorian Coastal Region and local geology}

In Ecuador, a major NNE-SSW suture zone separates the crystalline basement of cratonic South-America from the mafic oceanic igneous basement of the Western Andean Cordillera and the fore-arc region. The mafic basement is considered to be part of an oceanic plateau (Reynaud et al., 1999) of LateTuronian to Coniacian age $(88.8+/-1.6 \mathrm{Ma}$, Luzieux et al., 2006). During the Campanian, an intra-oceanic arc developed, which yielded thick sequences of volcaniclastic rocks (Ollson, 1942; Benítez, 1995), lavas (Lebrat et al., 1987; Luzieux et al., 2006) and intrusive rocks (Pichler and Aly, 1983). The basement blocks were accreted to western South-America either in the Late Santonian-Early Campanian (Lebrat et al., 1987; Kerr et al., 2002; Spikings et al., 2005) or in the LateCampanian-Maastrichtian (Spikings et al., 2001; Jaillard et al., 2004; Luzieux et al., 2006). The basement crops out in the region west of the city of Guayaquil, in a mountainous zone of
NNW-SSE orientation, named Cordillera Chongón-Colonche. The study area of this research, the region of Guayaquil, is slightly deformed and the rock units dip gently southwards in a monocline. Along the Perimetral ring way and in the quarries and hills north of Guayaquil, a north-south cross-section through the Cretaceous stratigraphy is exposed (Fig. 3). In the Coastal area, the oceanic plateau basement is named Piñón formation. It crops out in the northern part of the Cordillera Chongón-Colonche and consists of tholeitic basaltic-andesitic pillow lavas and massive flows intruded by doleritic-gabbroic stocks. The Las Orquídeas unit is considered as the upper member of the Piñon formation and consists of pillow basalts with an island-are signature of unknown age and with unclear stratigraphical relations (Reynaud et al., 1999; Luzieux et al., 2006). The overlying Calentura formation is $200-\mathrm{m}$-thick and consists of pelagic black shales, limestones and thin-bedded volcaniclastic intercalations. Micro-fossils indicate a Coniacian age for the basal part (Mendoza and Velasco, 2003; Luzieux et al., 2006). The overlying Cayo formation is a 2500 -m-thick sequence of marine volcaniclastic and sedimentary rocks, derived from an intra-oceanic volcanic arc. The basal part consists of coarse-grained thick sequences of volcaniclastic 


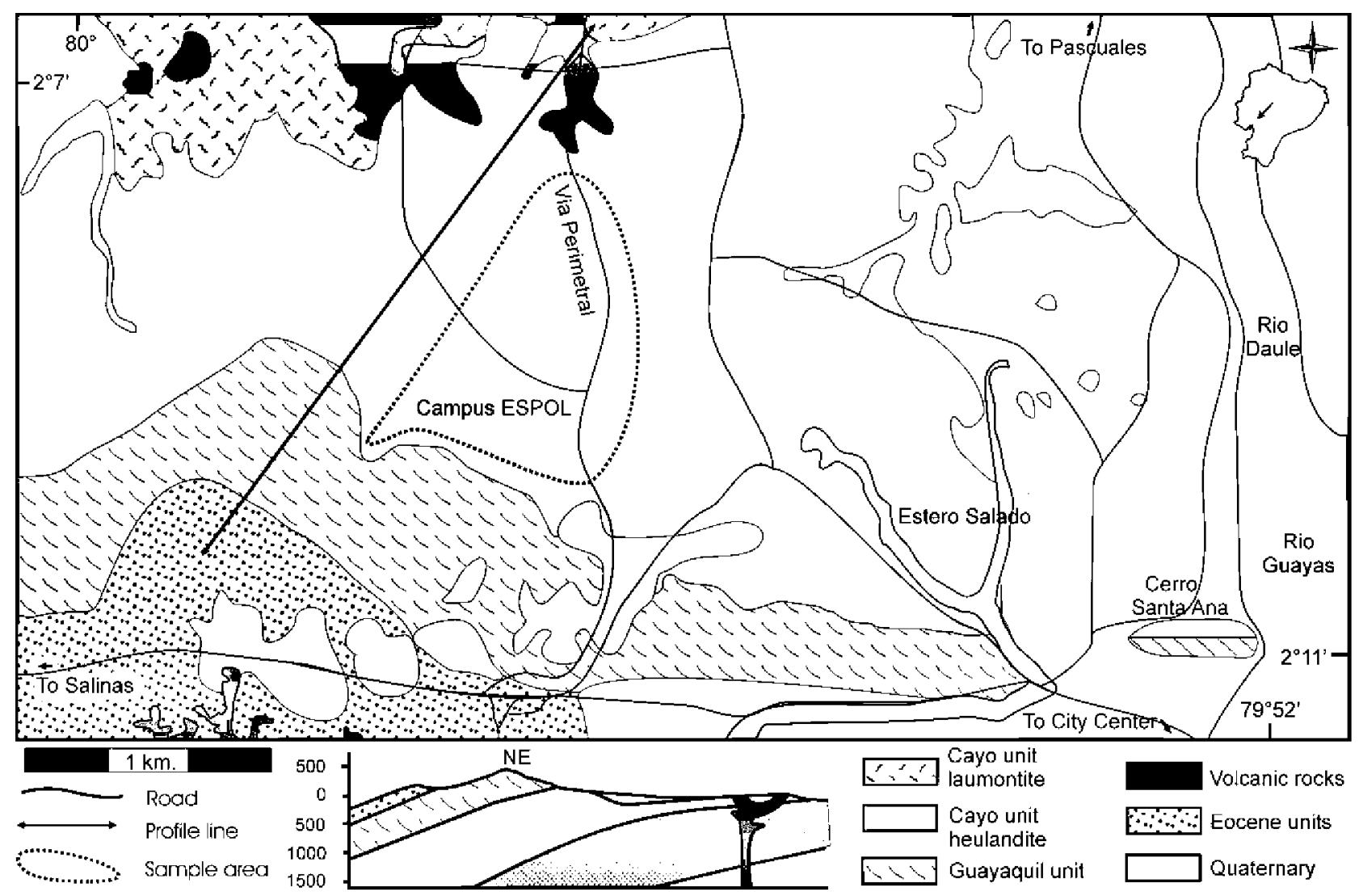

Fig. 2. Local geology. Modified from 1:50000 geological map Pascuales (ESPOL university, unpublished).

rocks, probably deposited contemporaneously with arc activity. Current work indicates a Middle-Campanian age for the base of the Cayo formation in the Rio Guaraguao (Vilema, pers. com.). The upper part, of Late-Campanian-Maastrichtian age, consists of turbidites and debris flows and displays an upward thinning and fining trend (Mendoza and Velasco, 2003). These strata are interpreted as the product of the erosion of an inactive volcanic arc (Thalmann, 1946; Wallrabe-Adams, 1990; Benítez 1990, 1995; Reynaud et al., 1999; Luzieux et al., 2006), and probably originate from andesitic-dacitic sources. The overlying Guayaquil formation of Maastrichtian to Late-Paleocene age consists of $400 \mathrm{~m}$ of pelagic shales, cherts, siliceous tuffs and some thinbedded turbidites and is entirely devoid of continental material (Thalmann, 1946; Faucher et al., 1971; Jaillard et al., 1995). The Guayaquil formation is unconformably overlain by the Early Eocene turbiditic limestones of the San Eduardo formation and the clastic sediments of the Ancón group (Benítez, 1995).

The studied area is located in the upper part of the Cayo formation, near the contact with the Guayaquil formation (Fig. 2). It corresponds to the upper units of the Cayo formation C3 (600 m) and C4 (300 m) of Benítez (1995).

\section{Materials and methods}

Samples were collected on outcrops along the Perimetral ring way in Guayaquil and on other outcrops, mainly creeks, on the campus domain of the ESPOL University (Fig. 2). Depositional sequences more than $10 \mathrm{~m}$ thick were described in detail along the Perimetral ring way. Thin section analysis using optical microscopy was performed to distinguish the different volcaniclastic and

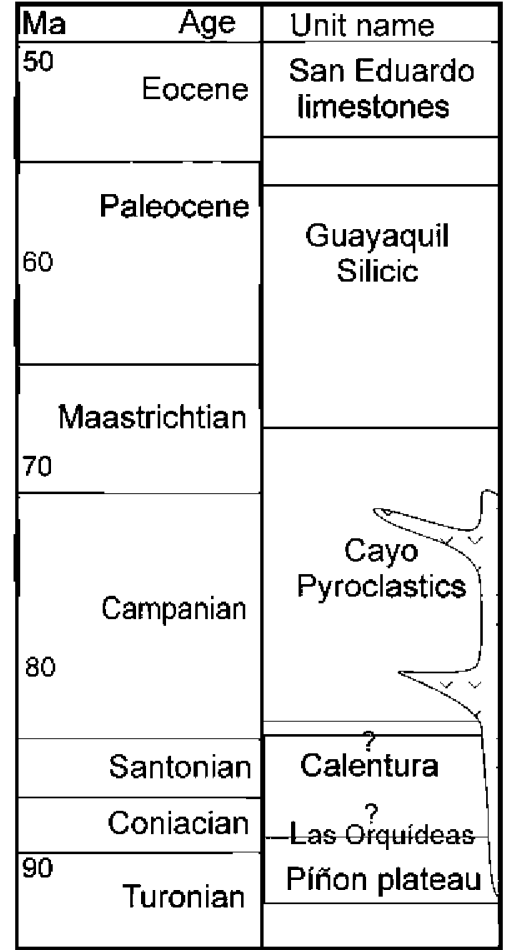

Fig. 3. Cretaceous stratigraphy. 
sedimentary rock types and to observe the alteration minerals. X-Ray powder diffraction (XRD) patterns were obtained with a Philips 1704 diffractometer using $\mathrm{CuK} \alpha$-radiaton with Ni-filter and a monochromator, operating at $45 \mathrm{kV}$ and $30 \mathrm{~mA}$. To investigate the thermal stability of the HEU-type zeolites, some samples were heated for $12 \mathrm{~h}$ at $200{ }^{\circ} \mathrm{C}, 300{ }^{\circ} \mathrm{C}$ and $450{ }^{\circ} \mathrm{C}$ respectively and analyzed after cooling using XRD. Quantitative analysis of 50 selected samples was carried out using the following standardized sample preparation procedure. Samples were ground by hand and sieved to $<500 \mu \mathrm{m}$, spiked with $10 \%$ of $\mathrm{ZnO}$ internal standard and ground in methanol for 5 min using a McCrone Micronizing Mill. Infrared spectroscopic analysis confirms that this preparation technique reduces the grain size to $<10 \mu \mathrm{m}$, which is the grain size required for quantitative analysis (Buhrke et al., 1998). The use of a McCrone Micronizing Mill and a grinding fluid minimizes amorphisation of zeolites in zeolite-quartz mixtures and avoids the creation of different grain-size populations. Random powder mounds were prepared using the side-loading technique (with frosted glass) to prevent preferred orientation (e.g. fibrous mordenite). Powder samples were placed in an equilibration chamber with an oversaturated $\mathrm{Mg}\left(\mathrm{NO}_{3}\right)_{2} \cdot 6 \mathrm{H}_{2} \mathrm{O}$ solution for at least $16 \mathrm{~h}$ prior to X-ray measurement to create an atmosphere with a constant relative humidity of $52 \%$. This technique is used to achieve complete hydration of the zeolites, which is especially important for samples containing laumontite, because this mineral can dehydrate at room temperature and under low relative humidity's (Buhrke et al., 1998). Quantitative X-ray analysis was carried out with a Philips PW1830 diffractometer with $\mathrm{CuK} \alpha$ radiation, graphite monochromator, $45 \mathrm{kV}$ and $35 \mathrm{~mA}, 0.02^{\circ}$ step size, $5-65^{\circ} 2 \theta$ and $2 \mathrm{~s}$ counting time per step. For the quantitative interpretation of the data the Rockjock ${ }^{\mathbb{B}}$ profile summation method was used (Eberl, 2003). In Rockjock the measured pattern is fitted to a calculated pattern composed of pure mineral standards measured under identical diffractometer settings. A Philips-505 Scanning Electron Microscope with EDAX 9000 detector was used to observe the habit of the different zeolite crystals on broken surfaces of the samples. Electron probe microanalysis (EPMA) with a Camecabox SX50 was performed to determine the chemical composition of HEU-type zeolites. An accelerating voltage of $15 \mathrm{keV}$ and a beam current of $20 \mathrm{nA}$ were used with a beam spot size of $5 \times 5 \mu \mathrm{m}$. The following mineral standards were used: wollastonite for $\mathrm{Si}$ and $\mathrm{Ca}$ (10 s counting time), synthetic sapphirine for $\mathrm{Al}(10 \mathrm{~s})$, oligoclase for $\mathrm{Na}$ (16 s), leucite for $\mathrm{K}(10 \mathrm{~s})$, olivine for $\mathrm{Mg}(16 \mathrm{~s})$, synthetic hematite for $\mathrm{Fe}(10 \mathrm{~s})$, rutile for $\mathrm{Ti}(10 \mathrm{~s})$, rhodonite for $\mathrm{Mn}(10 \mathrm{~s})$, strontianite for $\operatorname{Sr}(10 \mathrm{~s})$ and barite for $\mathrm{Ba}(10 \mathrm{~s})$. The values for the chemical balance error, as defined by Gottardi and Galli $(1985),\left(E_{\%}^{\%}=100\left[\mathrm{Al}+\mathrm{Fe}^{3+}\right]-(\mathrm{Na}+\mathrm{K})-2(\mathrm{Mg}+\mathrm{Ca})\right] /[(\mathrm{Na}+\mathrm{K})+2$ $(\mathrm{Mg}+\mathrm{Ca})]$ are all below $+/-10 \%$.

\section{Field observations}

The Cayo formation is a heterogeneous rock unit consisting of a wide range of different rock types. Up to now a local terminology of "agglomerados", "lutitas" and "lutitas tobaceas" is used to describe the different coarse and fine-grained rock types. It is not always clear if for example a lutita is a fine-grained pyroclastic, epiclastic or sedimentary rock. A distinction between these types has to be made because of their different zeolite content. Only layers of "green-blue lutitas", quite rare in the area, are actually exploited. A better petrographical description and a better terminology are needed. The classification of the volcaniclastic rock types used here is based on the grain size of volcaniclastic particles (Fisher and Schmincke, 1984).

All rocks described previously were deposited in a marine environment, as it is evidenced by the presence of marine micro-fossils (radiolaria, foraminifera) and algae fragments through the entire section. Benítez (1990) describes a very regular cyclic depositional pattern of marine "megaturbidites", sequences more than ten metres thick, interstratified with finergrained turbidites along the Perimetral ring way. Because the entire area is composed of these sequences, they are described here in detail. In Fig. 4 a schematic simplified cross-section is

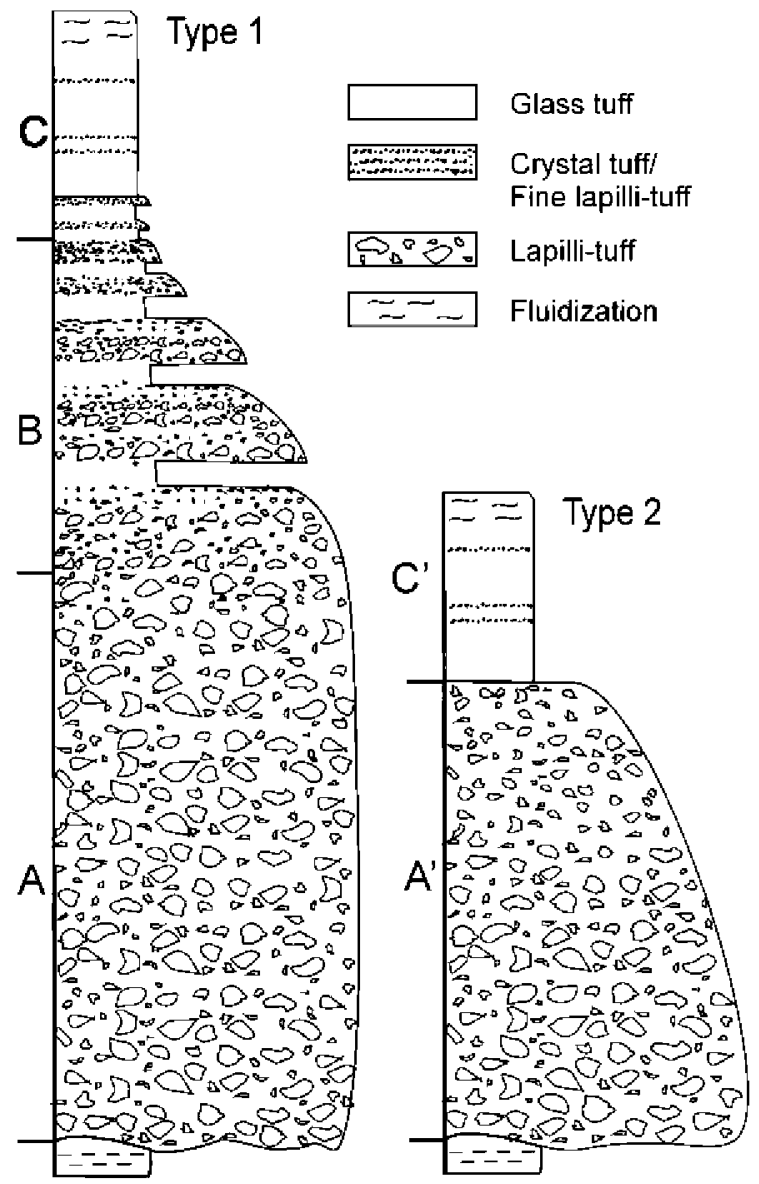

Fig. 4. Depositional sequences.

shown through a depositional sequence typical for the northern part of the study area (sequence type 1).

The basal part of a sequence (part A) consists of coarse lapilli-tuffs to tuff-breccia. It can be up to $25 \mathrm{~m}$ thick and covers about $70-80 \%$ of the complete sequence, although sequences consisting of $40 \%$ up to $100 \%$ lapilli-tuffs have been observed. This part is heterogeneous without stratification or grading. The bottom of the sequence is typically scoured into the fine-grained upper part of a previous sequence. A $100 \mathrm{~m}$ wide section was observed north of the study area where a thick lapilli-tuff sequence is in erosive contact with a stratified tuff or claystone. 2-3-metre deep gullies erode the previous sequence.

In most sequences the unstratified basal part is covered by a stratified part (part B), composed of alternating layers of lapillituffs, fine-grained crystal tuffs and homogeneous glass tuffs (up to 100 layers in one sequence). In the basal part lapilli-tuffs dominate, in the upper part crystal and glass tuffs dominate. A single layer can be of decimetre- to millimetre size. Both the entire sequence and each single bed is graded, becoming finer and thinner upwards. In tuffs a grading from crystal tuffs to fine pure glass tuffs can be observed. Layer contacts are sharp, with a concentration of heavy crystal fragments on top of erosive surfaces.

The upper part of the sequence (part C) is fine-grained, although grain-size changes are less pronounced, they are still present on a micro scale. The dominant lithology is a fine- 
grained homogeneous porous brown to green light-weight glass or crystal-glass tuff. Some homogeneous blue-green glass tuffs are exploited, if thick enough. Less common are heavier brown, green or grey siltstones to sandstones (epiclastics). Fluidisation structures are common in this part indicating a high water content during deposition. The top of the sequence typically consists of a $20-40 \mathrm{~cm}$ thick single layer of beige or intense green light-weight glass tuff, although this layer can be eroded by the massive lapilli-tuff part of the next sequence.

The sequence described above is typical for the Perimetral ring way NW of the ESPOL campus. On the southern ESPOL campus or on the southern part of the Via Perimetral, near the contact with the Guayaquil formation, some differences can be noted in the sequences (sequence type 2, Fig. 4). Depositional sequences are thinner and finer-grained in this area and lack clear stratification. A sequence consists typically of a basal lapilli-tuff part (part $A^{\prime}$ ) which is heterogeneous at the base becoming finer upwards towards a fine lapilli-tuff(typically $70 \%$ of a sequence). The upper part (part C') is a fine-grained brown or green crystalglass tuff with no pronounced grading, mostly in sharp contact with the lower part. Less common are heavier brown, green or grey siltstones to sandstones (epiclastics).

\section{Petrography}

The basal lapilli-tuff part of the sequence is commonly not well preserved, because of strong weathering, which seems to be layeror sequence-dependent. Weathered lapilli-tuffs have a low density, they are slightly compact and have a high porosity and an iron brown colour. Better preserved lapilli-tuffs are wellcemented, heavier, less porous, harder, with green or grey matrix and angular or semi-rounded clasts of millimetre to centimetresize. The main clasts are highly vesiculated unwelded pumice (green or brown colour macroscopically, caused by celadonite or Fe-rich smectite alteration), porphyritic basalt and andesite (red to black colour macroscopically). Decimetre-size clasts are reworked from underlying fine-grained strata. At the base of the sequence ash-size particles are rare in lapilli-tuffs and voids between lapilli are filled with HEU-type zeolites and calcite. Higher in the sequence is an altered ash-matrix consisting of fractured angular crystal fragments, some Y-shaped glass shard "ghosts" and an interlocking pattern of fine-grained zeolites (HEU-type zeolites or laumontite), clay minerals (Fe-rich smectite or a chlorite/smectite mixed layer, celadonite) and calcite. These minerals also replace most of the pumice and large HEU-type zeolites and laumontite fill vesicles in pumice and basalt fragments (crystal size up to $0.5 \mathrm{~mm}$ ). Crystal fragments are mainly plagioclase and pyroxene with minor K-feldspar, quartz and $\mathrm{Fe}$-Ti oxides. Fractures passing through grains and matrix are filled with calcite, HEU-type zeolites or laumontite. The overall fossil content is low, some algae fragments, foraminifera and radiolaria were determined.

The fine-grained tuffs in the stratified and upper part of the sequence consist mainly of altered glass and well preserved crystal fragments. Although all glass is completely replaced by finegrained zeolites (HEU-type zeolites and mordenite), quartz and smectite, Y-shaped glass shard textures are well preserved.
Millimetre- to centimetre thick laminae can be distinguished. Two types of laminae occur. In graded laminae Fe-Ti oxides are concentrated at the base, crystal fragments dominate the lower part and grade into glass shards in the upper part. Ungraded laminae predominantly consist of glass shards or crystal fragments. Erosive contacts can be recognized at the base of some laminae. Crystal fragments are mainly plagioclase and quartz and minor K-feldspar and $\mathrm{Fe}-\mathrm{Ti}$ oxides. Rounded green glass-fragments, small porphyritic rock fragments and micro-fossils are rare. In some pure glass tuffs a poorly developed preferential orientation of the long axis of the shards with the layering can be observed. Some heavier and compact epiclastic strata in the upper part of the sequence have a quartz-smectite or quartz-calcite-smectite matrix, a low residual glass content and a higher content in micro-fossils (radiolaria and pelagic foraminifera). In crystal-rich coarser rocks laminae rich in quartz and plagioclase alternate with laminae rich in micro-fossils. Zeolite crystals are rare in these lithologies and replace glass fragments or fill radiolaria.

\section{Mineralogy}

\subsection{Mineral assemblages}

All samples analyzed contain zeolites. Zeolitisation is observed only in the Cayo formation, whereas zeolites are absent in the overlying Guayaquil formation, which is dominated by quartz (southern part of Fig. 2). Four types of zeolites occur: HEU-type zeolites, laumontite, mordenite and analcime. HEU-type zeolites are the most common zeolites, occurring in most samples. They replace glass in the matrix of tuffs and lapilli-tuffs. They are present as small euhedral crystals replacing glass shards while large crystals fill vesicles in pumice and basalt fragments. They are also present in veins and/or replace calcite and plagioclase. Laumontite is the second most abundant zeolite. It was identified as a cement or filling vesicles mostly in coarse lapilli-tuffs, in the northern part of the study area, and in veins in the southern part. Mordenite was identified, mainly in small amounts, in silicic glass-tuffs. Analcime is rarely present in lapilli-tuffs. The main mineral phases besides the zeolite minerals are quartz (authigenic in matrix of finegrained rocks, detrital in crystal tuffs), mixed layer chlorite/ saponite and celadonite (in matrix and rimming glass shards and cavities), calcite (authigenic, fine-grained early formed phase in matrix or coarse-grained phase postdating HEU-type zeolites or fracture filling or detrital in limestone and algae fragments), plagioclase (mainly andesine) and $\mathrm{K}$-feldspar. Four associations of alteration minerals can be distinguished. (1) HEU-type zeolites + mixed layer chlorite/saponite + celadonite + quartz + calcite. (2) Laumontite + albite + mixed layer chlorite/saponite + HEU-type zeolites + calcite. (3) mordenite+quartz+HEU-type zeolites + celadonite. (4) analcime + mixed layer chlorite/saponite + HEU-type zeolites. The HEU-type zeolite (1), mordenite (3) and analcime (4) associations can be related to differences in composition of parent material, while the presence of laumontite (2), only in the upper part of the study area, reflects evolution to higher-grade alteration facies in coarse-grained, permeable beds. This association becomes dominant north of 
the study area. The low zeolite content in the region north of the studied area is explained by alteration to a higher-grade laumontite-albite metamorphic facies (Machiels et al., 2006).

\subsection{Quantitative mineralogical analysis}

The quantitative mineralogical data of 50 selected samples are listed in Table 1 . The zeolite content is highly variable in the rocks, reflecting the high variability in lithologies, composition and original glass content. In lapilli-tuffs, the zeolite content is variable $(20-45 \%)$. Associated alteration minerals are clay minerals $(6-36 \%$, high clay content in weathered samples), albite $(0-23 \%)$, quartz $(0-10 \%)$, K-feldspar $(<5 \%)$ and calcite $(0-9 \%$, veins and matrix). Relict magmatic minerals such as $\mathrm{Na}-\mathrm{Ca}$-plagioclase, pyroxene and $\mathrm{Fe}-\mathrm{Ti}$ oxides can be present in variable amounts $(6-46 \%)$.

Table 1

Quantitative mineralogical data

\begin{tabular}{|c|c|c|c|c|c|c|c|c|c|c|c|c|c|c|}
\hline No. & Coordinates & Rocktype & Heu-cli & Mor & Lau & Ana & Qtz & Alb & Fsp & $\mathrm{Cc}$ & $\mathrm{Px}$ & Clay & Other & Unid \\
\hline 1 & $0617210-9764644$ & Lapilli-tuff & 40 & & 1 & & 4 & 2 & 4 & 8 & 2 & 32 & 1 & 6 \\
\hline 2 & $0617214-9764594$ & Siltstone & 15 & & 1 & & 32 & 1 & 7 & 18 & & 27 & & 0 \\
\hline 3 & $0617257-9764140$ & Lutite, brown & 23 & & & & 30 & 2 & 10 & & 1 & 30 & 1 & 5 \\
\hline 5 & $0617481-9763742$ & Silstone, grey & 21 & & & & 14 & 6 & 18 & 21 & 2 & 15 & 2 & 2 \\
\hline 6 & $0617516-9763136$ & Silstone, grey & 29 & & & & 31 & 2 & 9 & & 1 & 30 & & 0 \\
\hline 7 & $0617402-9762444$ & Sandstone & 43 & & & & 3 & 5 & 17 & 1 & 4 & 23 & 1 & 4 \\
\hline 10 & $0617323-9762318$ & Lapilli-tuff & 28 & & & & 7 & 7 & 29 & 1 & 8 & 11 & 2 & 6 \\
\hline 11 & $0617323-9762308$ & Lapilli-tuff & 21 & & 7 & & & 17 & 22 & 4 & 6 & 11 & 3 & 8 \\
\hline 12 & $0617320-9762300$ & Lapilli-tuff & 29 & & 5 & & & 15 & 22 & 4 & 6 & 6 & 3 & 10 \\
\hline 13 & $0617317-9762292$ & Lapilli-tuff & 2 & & 22 & & 2 & 23 & 25 & 5 & 8 & 9 & 2 & 2 \\
\hline 14 & $0617314-9762284$ & Lapilli-tuff & 23 & & 7 & & & 16 & 22 & 3 & 6 & 15 & 2 & 7 \\
\hline 15 & $0617307-9762274$ & Lapilli-tuff & 28 & & 5 & & & 15 & 21 & 4 & 6 & 9 & 3 & 9 \\
\hline 20 & $0617292-9762242$ & Siltstone & 60 & 3 & & & 11 & & 4 & 1 & 2 & 6 & & 12 \\
\hline 21 & $0617293-9762234$ & Lapilli-tuff & 22 & & & & 10 & 5 & 33 & 4 & 4 & 19 & 2 & 0 \\
\hline 22 & $0617288-9762212$ & Lapilli-tuff & 25 & & 4 & & & 13 & 23 & 3 & 7 & 13 & 2 & 10 \\
\hline 23 & $0617283-9762204$ & Lapilli-tuff & 44 & & & & 1 & 6 & 23 & 3 & 6 & 16 & 3 & 0 \\
\hline 24 & $0617279-9762192$ & Lapilli-tuff & 40 & 1 & & & 2 & 4 & 30 & 2 & 5 & 11 & 2 & 2 \\
\hline 25 & $0617275-9762178$ & Siltstone & 43 & 5 & & & 7 & 3 & 22 & 1 & 3 & 5 & 2 & 9 \\
\hline 26 & $0617277-9762170$ & Lutite & 61 & 9 & & & 9 & 1 & 4 & & 2 & 4 & 1 & 11 \\
\hline 27 & $0617269-9762158$ & Siltstone & 37 & & & & 11 & 1 & 22 & 3 & 4 & 9 & 2 & 11 \\
\hline 28 & $0617269-9762152$ & Lapilli-tuff & 21 & 1 & & & 9 & 4 & 41 & 7 & 5 & 11 & 2 & 0 \\
\hline 29 & $0617264-9762140$ & Lapilli-tuff & 30 & 1 & & & 5 & 4 & 31 & 7 & 4 & 16 & 2 & 0 \\
\hline 30 & $0617260-9762132$ & Lutite & 28 & & & & 43 & 2 & 6 & & & 13 & & 8 \\
\hline 31 & $0617256-9762120$ & Lapilli-tuff & 33 & & & & 33 & & 7 & 4 & & 22 & & 1 \\
\hline 32 & $0617251-9762104$ & Lutite & 27 & & & & 33 & 3 & 7 & 7 & 1 & 23 & 1 & 0 \\
\hline 41 & $0616045-9761664$ & Lutite, beige & 10 & & & & 49 & 1 & 5 & & & 33 & & 2 \\
\hline 42 & $0615990-9761612$ & Lutite, brown & 21 & & & & 50 & 1 & 8 & & 3 & 17 & & 0 \\
\hline 43 & $0615974-9761486$ & Lutite; lightgrey & 20 & & & & 38 & 2 & 14 & & 3 & 23 & & 0 \\
\hline 44 & $0615941-9761390$ & Lapilli-tuff & 33 & & & & 7 & 3 & 20 & 3 & 3 & 25 & 1 & 5 \\
\hline 45 & $0615955-9761406$ & Lutite, green & 31 & & & & 52 & & 4 & & & 9 & & 4 \\
\hline 46 & $0614521-9762010$ & Lapilli-tuff & 28 & & & & 3 & 2 & 15 & & 3 & 36 & 1 & 13 \\
\hline 47 & $0614430-9761660$ & Silstone, brown & 16 & 1 & 1 & & 39 & 2 & 11 & 1 & & 19 & & 10 \\
\hline 48 & $0617183-9761066$ & Siltstone, brown & 19 & & & & 38 & 1 & 15 & & 2 & 20 & 2 & 3 \\
\hline 49 & $0617430-9760520$ & Siltstone, brown & 45 & & & & 28 & & 1 & & & 16 & & 10 \\
\hline 50 & $0617430-9760520$ & Sandstone & 15 & & & & 15 & 5 & 33 & & 1 & 27 & 1 & 3 \\
\hline
\end{tabular}

Coordinates in UTM UPS Prov. S. Am. ' 56 (sector 17 M). Heu-cli: heulandite-clinoptilolite, mor: mordenite, qtz: quartz, alb: albite, fsp: Ca-plagioclase, cc: calcite, px: pyroxene, clay: total clay minerals, other: Fe-Ti oxides, unid: unidentified. 


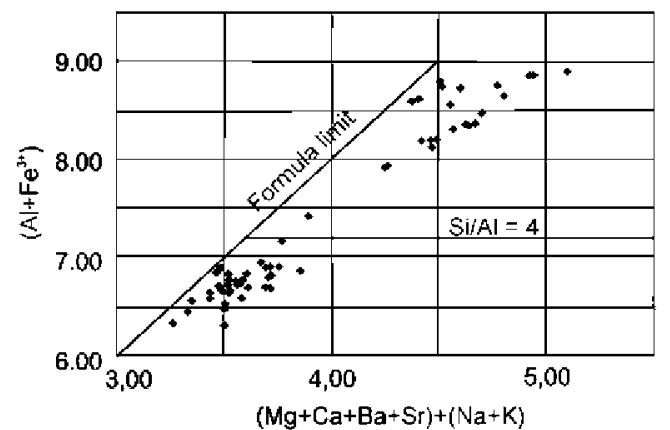

Fig. 5. $\mathrm{Al}+\mathrm{Fe}^{3+}$ versus $\mathrm{Na}+\mathrm{K}+\mathrm{Ca}+\mathrm{Mg}+\mathrm{Sr}+\mathrm{Ba}$ plot of EPMA results.

In fine-grained rocks, the zeolite content is more variable. The zeolite content is highest in altered crystal- and glass tuffs (40-60\%). Other fine-grained rocks, mostly reworked sedimentary rocks, have a low zeolite content (10-30\%) and a high quartz $(30-50 \%)$, feldspar $(10-20 \%)$ and clay mineral content $(20-30 \%)$.

\subsection{Heulandite-clinoptilolite solid solution series}

Theoretically the composition of the heulandite-clinoptilolite solid solution series varies between the end-members heulandite $\left(\mathrm{Na}, \mathrm{K}, \mathrm{Ca}_{0.5}\right)_{10}\left(\mathrm{Al}_{10} \mathrm{Si}_{26} \mathrm{O}_{72}\right) \cdot 24 \mathrm{H}_{2} \mathrm{O}$ which has a $\mathrm{Si} / \mathrm{Al}$ ratio of
2.6 and clinoptilolite $\left(\mathrm{Na}, \mathrm{K}, \mathrm{Ca}_{0.5}\right)_{5.4}\left(\mathrm{Al}_{5.4} \mathrm{Si}_{30.6} \mathrm{O}_{72}\right) \cdot 20 \mathrm{H}_{2} \mathrm{O}$ which has a Si/Al ratio of 5.6. Members of this series with a $\mathrm{Si} / \mathrm{Al}$ ratio $<4$ are characterized heulandites, whereas members with a ratio $>4$ are characterized clinoptilolites (Bish and Boak, 2001). Heulandite is also typically richer in $\mathrm{Ca}$ than clinoptilolite. Both minerals have similar crystal structure and are difficult to distinguish by XRD analysis, although there are some small differences in the intensity of the diffraction maxima. A method to distinguish between both end members is the different thermal stability of the minerals. Alietti (1972) divided heulandites and clinoptilolites into three groups based on their thermal stabilities. Heulandites type-1 (Si/A1 2.6-3.52) undergo an irreversible transformation to contracted B or I-phases during heating and their structure is completely destroyed after heating to $450{ }^{\circ} \mathrm{C}$. Type-2 heulandites ( $\mathrm{Si} / \mathrm{A} 13.57-4.31$ ) may or may not transform to a $\mathrm{B}$-phase and undergo partial destruction at $450{ }^{\circ} \mathrm{C}$. Type-3 heulandites or clinoptilolites ( $\mathrm{Si} / \mathrm{Al} \mathrm{4.12-5.7)}$ do not transform to a $\mathrm{B}$ phase and are stable commonly up to $\sim 650^{\circ} \mathrm{C}$. The samples were heated for $13 \mathrm{~h}$ at 200,300 and $450{ }^{\circ} \mathrm{C}$. Transformation to contracted phases could be observed at lower temperatures and in most samples The HEU-type zeolites became completely X-ray amorphous when heated at $450^{\circ} \mathrm{C}$ for $13 \mathrm{~h}$. This indicates the presence of a Ca-rich HEU-type zeolite with an intermediate or low $\mathrm{Si} / \mathrm{Al}$ ratio $(<4.31)$. However these results are only partially in accordance with the EPMA-results (cf. infra).

Table 2

Representative EPMA analyses of heulandite-clinoptilolite

\begin{tabular}{|c|c|c|c|c|c|c|c|c|}
\hline & Heulandite & Clinoptilolite & Clinoptilolite & Heulandite & Clinoptilolite & Clinoptilolite & Clinoptilolite & Heulandite \\
\hline & s 51 & s 36 & s 9-1 & s $9-2$ & s 9-3 & s 9-4 & s $9-5$ & s 9-6 \\
\hline & Vein & Glass tuff & $\begin{array}{l}\text { Lapilli-tuff } \\
\text { vesicle rimm }\end{array}$ & $\begin{array}{l}\text { Lapilli-tuff } \\
\text { vesicle centre }\end{array}$ & $\begin{array}{l}\text { Lapilli-tuff } \\
\text { glass }\end{array}$ & $\begin{array}{l}\text { Lapilli-tuff } \\
\text { glass }\end{array}$ & $\begin{array}{l}\text { Lapilli-tuff } \\
\text { voids rimm }\end{array}$ & $\begin{array}{l}\text { Lapilli-tuff } \\
\text { voids central }\end{array}$ \\
\hline $\mathrm{SiO}_{2}$ & 59.56 & 65.92 & 66.30 & 60.55 & 64.07 & 68.92 & 68.16 & 60.40 \\
\hline $\mathrm{Al}_{2} \mathrm{O}_{3}$ & 15.78 & 12.91 & 12.86 & 15.34 & 12.73 & 12.94 & 12.00 & 15.29 \\
\hline $\mathrm{Fe}_{2} \mathrm{O}_{3}$ & 0.00 & 0.22 & 0.00 & 0.00 & 0.00 & 0.13 & 0.23 & 0.00 \\
\hline $\mathrm{BaO}$ & 0.39 & 0.00 & 0.00 & 0.00 & 0.00 & 0.00 & 0.00 & 0.00 \\
\hline $\mathrm{SrO}$ & 0.33 & 0.00 & 0.00 & 0.16 & 0.00 & 0.00 & 0.00 & 0.16 \\
\hline $\mathrm{CaO}$ & 7.81 & 6.04 & 6.63 & 8.17 & 6.12 & 5.87 & 5.31 & 8.14 \\
\hline $\mathrm{Na}_{2} \mathrm{O}$ & 0.24 & 0.20 & 0.22 & 0.36 & 0.25 & 0.26 & 0.16 & 0.35 \\
\hline $\mathrm{K}_{2} \mathrm{O}$ & 0.52 & 0.20 & 0.25 & 0.53 & 0.28 & 0.19 & 0.15 & 0.49 \\
\hline Total & 84.66 & 85.96 & 86.43 & 85.12 & 83.80 & 88.85 & 86.87 & 84.83 \\
\hline $\mathrm{Mn}$ & 0.00 & 0.00 & 0.00 & 0.00 & 0.00 & 0.00 & 0.00 & 0.00 \\
\hline $\mathrm{Mg}$ & 0.02 & 0.31 & 0.11 & 0.00 & 0.24 & 0.34 & 0.56 & 0.00 \\
\hline $\mathrm{Ba}$ & 0.07 & 0.00 & 0.00 & 0.00 & 0.00 & 0.00 & 0.00 & 0.00 \\
\hline $\mathrm{Sr}$ & 0.09 & 0.00 & 0.00 & 0.04 & 0.00 & 0.00 & 0.00 & 0.04 \\
\hline $\mathrm{Ca}$ & 3.86 & 2.87 & 3.14 & 3.99 & 2.99 & 2.69 & 2.48 & 3.99 \\
\hline $\mathrm{Na}$ & 0.22 & 0.17 & 0.19 & 0.32 & 0.22 & 0.21 & 0.14 & 0.31 \\
\hline K & 0.30 & 0.11 & 0.14 & 0.31 & 0.16 & 0.10 & 0.08 & 0.29 \\
\hline $\mathrm{O}$ & 72 & 72 & 72 & 72 & 72 & 72 & 72 & 72 \\
\hline $\mathrm{Si} / \mathrm{Al}$ & 3.20 & 4.33 & 4.37 & 3.35 & 4.27 & 4.52 & 4.82 & 3.35 \\
\hline $\mathrm{E} \%$ & 3.58 & 2.85 & -1.36 & -2.95 & 0.01 & 2.83 & 0.37 & 2.65 \\
\hline
\end{tabular}

E\%:chemical balance-error function (Gottardi and Galli 1985). 


\section{SEM-EDX and EPMA analysis}

Several samples have been studied by Scanning Electron Microscopy. The observed zeolite crystals form an interlocking pattern of tabular crystals, typical for HEU-type zeolites. The latter usually replace glass shards, fill the matrix of glass tuffs, crystal tuffs and lapilli-tuffs and the matrix of lithic clasts, they fill vesicles and intragranular porosity and replace plagioclase and calcite. Five samples were selected for EPMA analysis, two glass tuffs and three lapilli-tuffs. The $\mathrm{Si} / \mathrm{Al}$ data of the HEUtype zeolites are plotted in $\mathrm{a}\left(\mathrm{Al}+\mathrm{Fe}^{3+}\right)$ vs. $(\mathrm{Mg}+\mathrm{Ca}+\mathrm{Ba}+\mathrm{Sr})+$ $(\mathrm{Na}+\mathrm{K})$ diagram (Fig. 5). Some representative analyses of HEU-type zeolites are given in Table 2. The $\mathrm{Si} / \mathrm{Al}$ ratio of HEU-type zeolites ranges from 3.06 to 4.82 . All analyses in matrix and glass shards of tuffs correspond to clinoptilolite (mean Si/Al 4.35). In lapilli-tuffs, a clinoptilolite (mean Si/Al 4.38) and a heulandite (mean Si/Al 3.30) population can be distinguished (Fig. 5). Clinoptilolite occurs in the matrix, replaces glass and fills vesicles. Larger vesicles are rimmed by clinoptilolite whereas heulandite fills the central part. Heulandite also occurs in veins passing through tuffs and lapilli-tuffs. Both clinoptilolite and heulandite are very rich in calcium. The mean Monovalent/(Monovalent+ Divalent) value $(\mathrm{Na}+\mathrm{K})$ / $(\mathrm{Na}+\mathrm{K}+\mathrm{Ca}+\mathrm{Mg}+\mathrm{Sr}+\mathrm{Ba})$ is 0.15 with a minimum of 0.06 and a maximum of 0.36 . These high $\mathrm{Ca}$-values are confirmed by cationexchange tests (unpublished data).

\section{Discussion and conclusions}

At this stage of research, a burial diagenesis model is proposed for the zeolitisation of the volcaniclastic deposits. A pattern of vertical zonation can be distinguished, especially in the Guayaquil area, but this zonation is influenced by the high variability in composition and structure of the different lithologies.

\subsection{Depositional setting}

In several publications the (upper) Cayo formation is considered as the product of the erosion of an inactive volcanic arc (Thalmann, 1946; Wallrabe-Adams, 1990; Benítez 1990, 1995; Reynaud et al., 1999; Luzieux et al., 2006). Therefore the rocks are described as megaturbidites, debris flows and turbidites. However, the depositional sequences described previously should be interpreted as derived from an active volcanic arc. Intense diagenetic alteration and weathering resulted in an apparent "detrital" appearance of the rocks. The regular cyclic depositional pattern observed in the area is considered typical for marine pyroclastic deposits located near an active volcanic source which has been described in various similar volcanic regions (Fiske and Matsuda, 1964; Fisher and Schmincke, 1984; Schneider et al., 2004). The depositional sequences are interpreted as sub aqueous pyroclastic flows (part A) associated with fallout ash sedimentation and/or turbiditic reworking (part B,C). Each eruptive-depositional cycle started with initial fallout ash forming a thin tuff layer at the base of the sequence. A highly explosive eruptive event initiated heterogeneous unsorted and ungraded pyroclastic flow deposits, more than $10 \mathrm{~m}$ thick (Fiske and Matsuda, 1964). It is clear that these pyroclastic flows are highly energetic, as seen by the deep erosion in underlaying sequences and the presence of large tuff clasts from previous sequences. After the initial explosive event, during the waning of the eruptive stage, smaller eruptions yielded the typical double graded upper part of the sequence, consisting mainly of fallout ash, and minor smaller pyroclastic flow deposits, surges and turbidites (Fisher and Schmincke, 1984). A highly energetic depositional process is not considered possible for the deposition of fine-grained glass tuffs, because fragile glass shard structures are well preserved. The majority of these tuffs were probably deposited from the water column, which caused segregation of crystal fragments and light-weight glass fragments. Eroded surfaces indicate that part of these tuffs was reworked after initial deposition, and can thus be considered as epiclastic. The highly eruptive character of the volcano is proved by the high vesicularity of the pumice and the high content of Y-shaped glass shards representing disruption of pumice bubble walls by gas exsolution. Basaltic and andesitic fragments present in pyroclastic flow deposits represent non explosive lava extrusion stages of this volcanism. Alternation of intermediate lava extrusion phases and silicic explosive phases is typical for a strato volcano in a calcalkaline island arc, which is consistent with the data obtained by previous investigations (Wallrabbe-Adams, 1990; Benítez, 1990; Reynaud et al., 1999).

\subsection{Mineralogy}

The main zeolite mineral in the study area, occurring in all rock types, belongs to the heulandite-clinoptilolite solid solution series, in accordance with previous investigations (López et al., 2002; Nazareno et al., 2002). From X-ray data, heating experiments, SEM-EDX and EPMA analyses, it can be concluded that both clinoptilolite and heulandite occur, clustering in two groups with mean $\mathrm{Si} / \mathrm{A} 1$ values of 4.35 and 3.30 respectively. All analysed samples are rich in $\mathrm{Ca}$ with a mean $\mathrm{M} /(\mathrm{M}+\mathrm{D})$ ratio of 0.15 . Laumontite is less common, mainly occurring in lapilli-tuffs in the northern part of the study area. Analcime was identified, but is rare in the area. Mordenite is present in silicic green-blue tuffs, the only lithology actually exploited in the area. These tuff layers compose only a small percentage of the total thickness of the Cayo formation. The new quantitative data given in this work, suggest that other rock types should be considered for exploitation as well. Nevertheless, the overall low zeolite content of the Cayo formation in the Guayaquil area limits the possible application of the deposit in this area. Investigation of the Cayo formation west of Guayaquil, in the $100 \mathrm{~km}$ long Cordillera Chongón-Colonche, where new zeolite quarries were initiated recently, is now in progress. This deposit is of great importance for Ecuador, considering its enormous outcrop area (more than $10,000 \mathrm{~km}^{2}$ ). The zeolite minerals of this deposit could be used for the decontamination of local urban and industrial waste water, for use in agriculture and cement industry, etc. 


\section{Acknowledgments}

This research has been supported by the School of Mines (ETSIM) of the Polytechnic University of Madrid (Spain), the Applied geology and mineralogy research group of the Catholic University of Leuven (Belgium) and the departments of Earth Sciences and Material Engineering of the Escuela Superior Politécnica del Litoral (ESPOL) of Guayaquil (Ecuador).

\section{References}

Alietti, A., 1972. Polymorphism and crystal-chemistry of heulandites and clinoptilolites. American Mineralogist 57, 1448-1462.

Benítez, S., 1990. Estratigrafía de las Formaciones Cayo y Guayaquil en la Cordillera Chongón Colonche: Hacia una redefinición. Geociencia, Revista del CIGMP-Guayaquil 3:7-11, 4:18-20, 5:11-14.

Benítez, S., 1995. Evolution géodynamique de la province côtière sudÉquatorienne au Crétacé Supérieur-Tertiare. Géologie Alpine 71, 3-163.

Bish, D.L., Boak, J.M., 2001. Clinoptilolite-Heulandite nomenclature. In: Bish, D.L., Ming, D.W. (Eds.), Natural Zeolites: Occurrence, Properties, Applications. Mineralogical Society of America, Washington D.C., pp. 207-215.

Buhrke, V.E., Jenkins, R., Smith, D.K., 1998. Preparation of Specimens for $\mathrm{X}$-ray Fluorescence and X-ray Diffraction Analysis. John Wiley and Sons, New York.

Eberl, D.D., 2003. User's Guide to Rockjock - A Program for Determining Quantitative Mineralogy from Powder X-ray Diffraction Data. U.S. Geological Survey Open-File report 03-78, Colorado.

Faucher, B., Vernet, R., Bizon, G., Bizon, J.J., Grekoff, N., Lys, M., Sigal, J., 1971. Sedimentary Formations in Ecuador: A Stratigraphic and Micropaleontological Survey. Bureau Études Indust. Coop. Inst. Fr. Pétrole (BEICIP), Paris.

Fisher, R.V., Schmincke, H.U., 1984. Pyroclastic Rocks. Springer-Verlag, Berlin.

Fiske, R.S., Matsuda, T., 1964. Submarine equivalents of ash flows in the Tokiwa Formation, Japan. American Journal of Science. 262, 76-106.

Gottardi, G., Galli, E., 1985. Natural Zeolites. Springer-Verlag, Berlin.

Jaillard, E., Ordeñez, M., Suárez, J., Toro, J., Iza, D., Lugo, W., 2004. Stratigraphy of the late Cretaceous-Paleogene deposits of the Cordillera Occidental of central Ecuador: geodynamic implications. Journal of South American Earth Sciences 17, 49-58.

Jaillard, É., Ordeñez, M., Benítez, S., Berrones, G., Jiménez, N., Montenegro, G., Zambrano, I., 1995. Basin development in an accretionary, oceanic-floored forearc setting: southern coastal Ecuador during late Cretaceous to late Eocene times. In: Tankard, A.J., Suárez, R., Welsink, H.J. (Eds.), Petroleum Basins of South America. American Association of Petroleum Geologists Memoir, vol. 62, pp. 615-631.

Kerr, A.C., Aspen, J.A., Tarney, J., Pilatasig, L.F., 2002. The nature and provenance of accreted oceanic terranes in western Ecuador: geochemical and tectonic constraints. Journal of the Geological Society of London 159, $577-594$.

Lebrat, M., Megard, F., Dupuy, C., Dostal, J., 1987. Geochemistry and tectonic setting of pre-collision Cretaceous and Paleogene volcanic rocks of Ecuador. Geologic society of America Bulletin 99 (4), 569-578.
López, K., Morante, F., Botto, L.I., Adhemazar, J., 2002. Geología y mineralogía de zeolitas al oeste de Guayaquil, provincia del Guayas-Ecuador. Memorias del XV Congreso Geológico Boliviano. Revista técnica de yacimientos petrolíferos fiscales Bolivianas 20, Cochabamba, Bolivia, pp. 250-253.

Luzieux, L.D.A., Heller, F., Spikings, R., Vallejo, C.F., Winkler, W., 2006 Origin and Cretaceous tectonic history of the coastal Ecuadorian forearc between $1^{\circ} \mathrm{N}$ and $3^{\circ} \mathrm{S}$ : Paleomagnetic, radiometric and fossil evidence. Earth and Planetary Science Letters 249 (3-4), 400-414.

Machiels, L., Snellings, R., Morante, F., Elsen, J., Paredes, C., 2006. Mineralogía Cuantitativa de los Depósitos de Zeolitas en la Costa del Ecuador. Revista Tecnológica ESPOL 19, 41-48.

Mamberti, M., Lapierre, H., Bosch, D., Jaillard, E., Ethien, R., Hernandez, J., Polvé, M., 2003. Accreted fragments of the Late Cretaceous CaribbeanColombian Plateau in Ecuador. Lithos 66, 173-199.

Morante, F., 2004. Las zeolitas de la Costa de Ecuador (Guayaquil): geologia, caracterizacion y aplicationes. Ph.D. Thesis, Universidad Politécnica de Madrid, Escuela Técnica Superior de Ingenieros de Minas de Madrid, Spain

Mendoza, K., Velasco, M.L., 2003. Estudio Geológico del Miembro Calentura de la Formación Cayo en el Flanco Oriental de la Cordillera Chongón Colonche. Masters thesis. University of Guayaquil, Ecuador.

Nazareno, J., Peña, E., Morante, F., 2002. Gestion del movimiento de tierras y aprovechamiento de las zeolitas naturales existentes en el parque technologico campus ESPOL. Revista Technológica ESPOL 15, 50-57.

Ollson, A.A., 1942. Tertiary deposits of north-western South America and Panama. Proceedings of the 8th American Sciences Congress, vol. 4 pp. 231-287. Washington D.C.

Pichler, H., Aly, S., 1983. Neue K-Ar-Alter plutonischer Gesteine in Ecuador Zeitschrift Deutsche geologische gesellschaft 134, 495-506.

Reynaud, C., Jaillard, E., Lapierre, H., Mamberti, M., Mascle, G.H., 1999 Oceanic plateau and island arcs of southwestern Ecuador: their place in the geodynamic evolution of northwestern South America. Tectonophysics 307, $235-254$.

Robalino, P., Morante, F., Ramos, V., Egüez, H., 2005. Caracterización Basica de las zeolitas (Fm. Cayo-Ecuador) para su aplicación como material puzolánico. Internal report ESPOL university, Guayaquil, Ecuador.

Schneider, J., Torrado, F.J.P., Torrente, D.G., Wassmer, P., Santana, M.C.C., Carracedo, J., 2004. Sedimentary signatures of the entrance of coarsegrained volcaniclastic flows into the sea: the example of the breccia units of the Las Palmas Detritic Formation (Mio-Pliocene, Gran Canaria, Eastern Atlantic, Spain). Journal of Volcanology and Geothermal Research 138, 295-323.

Spikings, R.A., Winkler, W., Seward, D., Handler, R., 2001. Along-strike variations in the thermal and tectonic response of the continental Ecuadorian Andes to the collision with heterogeneous oceanic crust. Earth and Planetary Science letters 186, 57-73.

Spikings, R.A., Winkler, W., Hughes, R.A., Handler, R., 2005. Thermochronology of allochthonous terranes in Ecuador: unravelling the accretionary and post-accretionary history of the Northern Andes. Tectonophysics 399, $195-220$.

Thalmann, H., 1946. Micropaleontology of Upper Cretaceous and Paleoceno in Westem Ecuador. American Association of Petroleum Geologists Bulletin 30, $337-347$.

Wallrabe-Adams, H.-J., 1990. Petrology and geotectonic development of the Western Ecuadorian Andes: the Basic Igneous Complex. Tectonophysics, 185, 163-182. 